\title{
Salmonella Typhimurium Treated by Gamma Radiation as an Approach for Cancer Management
}

\author{
IBRAHIM H. BORAI, Ph.D.*; ZAHIRA S. TAWFIK, Ph.D.**; EMAN N. ALY, Ph.D.***; \\ SAWSAN MOHAMMED EL-SONBATY, Ph.D.** and NEVEEN A. MOHAMED, M.Sc.** \\ The Department of Biochemistry, Faculty of Science, Ain-Shams University* and The Departments of Radiation \\ Microbiology** and Radiation Biology***, National Center for Radiation Research and Technology, Atomic Energy \\ Authority, Cairo, Egypt
}

\begin{abstract}
Background: Salmonellae are gram-negative, facultative anaerobes, it can survive and colonize in hypoxic environment of the tumor, leading to a substantial reduction in the tumor size. Bacteria can be attenuated by radiation which resulted in complete loss of replicative ability but remained metabolically active.
\end{abstract}

Aim of the Work: This study was conducted to evaluate the efficiency of $\psi$-radiation as a tool to decrease the virulence of Salmonella typhimurium wild type strain ATCC 14028 (S. typhimurium.WT.) capable of tumor regression.

Methods: Exposure of Salmonella typhimurium wild type strain (S.typhimurium.WT.) to different doses of $\psi$-radiation, testing S.typhimurium.WT. that exposed to different doses of $\psi$ radiation for cytotoxic activity in vitro, and its pathogenicity in mice as well as the wild type strain was assessed. The antitumor activity of the $\psi$-irradiated Salmonella in vivo was tested as well. Sixty adult male weighty $20-25 \mathrm{~g}$ were used for this purpose and the mice divided into 6 experimental group, three of these groups were mice bearing EACs solid tumor, after the tumor volume reached approximately $1 \mathrm{~cm}^{3}$, the mice were treated with S.typhimurium.WT. parent strain and S.typhimurium.WT. exposed to 1and $4 \mathrm{kGy} \psi$-irradiation dose histopathological analysis, as well as, proliferation and immunological biomarker, was assessed. The study has been carried out for last three years in the National Center for Radiation Research and technology, Atomic Energy Authority, Egypt.

Results: Results showed a reduction in S.typhimurium.WT. viable count with the increase of $\psi$-radiation exposure dose, also a highly significant inhabitation in EAC cells count \% was occurred when S.typhimurium.WT. exposed to $\psi$ radiation at dose of 1 and $4 \mathrm{kGy}$, it was found S.typhimurium $\psi-1 \mathrm{kGy}$ give a high inhabitation percentage in cell line and became less virulent to mice than S.typhimurium wild type strain, results revealed that, treatment with $\mathrm{S}$. typhimurium $\psi 1 \mathrm{kGy}$ caused retardation in tumor growth in mice bearing tumor groups more than the wild type strain do. This was leading to a reduction in tumor volume accompanied with a significant increase in caspase- 3 activity. In addition, histopathological

Correspondence to: Dr. Ibrahim H. Borai, The Department of Biochemistry, Faculty of Science, Ain-Shams University analysis revealed that irradiated Salmonella achieve improvement of the muscular thigh tissue compared to EAC tumor bearing mice.

Conclusion: The exposure of S.typhimurium.WT. to $\psi-$ radiation decreases its virulence in mice and increase its antitumor activity in vivo and in vitro.

Key Words: Salmonella typhimurium - Gamma radiation Antitumor activity.

\section{Introduction}

SALMONELLA enterica serovar typhimurium is a facultative anaerobic bacterium, gram-negative, flagellated which generally develops and grows preferably in a wide variety of tumor cells. In recent studies, it was shown that attenuated strains of S. enterica typhimurium served as antitumor agents, preferably growing within tumors in a ratio of 1000:1 when compared to normal tissues [1] The preference for tumor tissues can be explained for some facts such as; there is the adaptation of S. enterica typhimurium to grow in areas with low percentage of oxygen; increased availability of nutrients released by necrotic cells and decreased bactericidal activity of macrophages and granulocytic neutrophils in regions with low oxygen concentration. Positive pressure and irregularities in vascularization of the tumor mass also inhibit, but not entirely, the entry of antibodies and complement factors favoring the growth of S. enterica typhimurium $[2,3]$

Although in some experimental systems, activation of innate immunity can protect against tumor development, in most systems effective cancer immune surveillance responses require the additional expression of tumor antigens capable of propagating the expansion of effector $\mathrm{CD}^{4}+$ and CD T-cells. Thus, coordinated and balanced 
activation of both innate and adaptive immunity is needed to protect the host against a developing tumor, in addition, the tumor regression due to enhancement of apoptosis pathway the activation of caspas-3 activity [4,5]

The attenuation of this species in order to create antitumor carrier molecules have been widely used, thereby increasing the LD 50 causing shrinkage of melanoma in mice that received such attenuated strain [6]. Furthermore, attenuated strains which produce cytokines with the potential to stimulate the host immune response against tumors [7,8] .

Ultimately production of a promoter induced by hypoxia (HIP-1) enabling modulation of genes with their transcription increased in the areas of hypoxia in the tumor mass [9].

Ionizing and non-ionizing radiation has been used for years to produce bacterial mutants with same different traits, and characters such as attenuation to be less virulent in mice [10]

\section{Aim of the work:}

The present study aimed to search for the attenuated Variants of Salmonella typhimurium induced by gamma-irradiation as a simple low cost effective method, capable of tumor regression; suggesting a great potential for cancer therapy.

\section{Material and Methods}

- Microorganisms: Salmonella typhimurium 14028 ATCC (American Type Culture Collection) was obtained from Microbiological Resources Center, Cairo, Egypt, MIRCEN.

- Media: The following media were used for cultivation, numeration, recovery and determination of Salmonella typhimurium viable counts. The media were sterilized by autoclaving at $121^{\circ}$ for 20 minutes; nutrient broth, nutrient agar, Luria Bertani broth and Luria Bertani agar.

- Experimental animals: One hundreds and seventy of male Swiss Albino mice weighted about 23$25 \mathrm{~g}$ were obtained from Holding Company for Biological Products and Vaccines, Vacsera, Cairo, Egypt.

Animals were housed in animal house of National Center for Radiation Research and Technology (NCRRT) Cairo, Egypt. They were carried in accordance with the standard out line in guide for the care and use of laboratory animals (DHHS, publication 85-23) and regularly, received standard pellet feed and drinking water.
- Cell lines: Ehrlich Ascites Carcinoma cells (EAC). Cell line used in this study was kindly supplied by the National Cancer Institute (NCI), Cairo University, Egypt. Tumor cells were maintained by weekly intraperitoneal (i.p) transplantation of $2.5 \times 10^{6}$ cells per male mice [11].

- Tumor transplantation: Solid tumors were obtained by intramuscular (I.M) injection of $0.2 \mathrm{ml}$ of AEC cells (contains $2.5 \times 10^{6}$ viable EAC cells) in the right thigh of the lower limb of each Swiss Albino mouse (Gupta et al., 2004) [12] Then, the tumor was left to grow until become in pulpable appearance to reach volume of $1 \mathrm{~cm}$ in control group and the volume was measured by caliper.

- Chemicals, reagents and kits: All chemicals obtained from sigma (USA), Mouse Caspase-3 Colorimetric Assay Kit manufactured by Abcam.

- Gamma irradiation facility: The Gamma (y) irradiation unit holding up to several thousand curries of Cobalt ${ }^{60}$ manufactured by Bhabba (INDIA) were used. The irradiation volume was approximately of $4000 \mathrm{CC}$. The dose rate at the time of the experiments was found to be $1 \mathrm{kGy} / 24$ minutes.

\section{1- Determination of sensitivity of Salmonella typhi.} WT parent strain towards Gamma radiation:

This procedure was carried out to investigate the sensitivity of Salmonella typhimurium.WT. strain towards y-radiation according to [13]. S. typhimurium.WT. strain was grown in nutrient broth and incubated for $18 \mathrm{hr}$ at $37^{\circ} \mathrm{C}$. The cell culture was divided equally into dry sterile screw copped plus test tube, immersed in ice water, and exposed to different y-irradiation doses in $\mathrm{CO}_{60}$ (Indian cell) as follow $(0.5,1,2,3,4,5,6,7, \mathrm{kGy})$. Immediately after irradiation, the irradiated samples and their control (non-irradiated one) were removed and serially diluted in physiological saline $(0.9 \%)$. Samples were shaken very well and $0.1 \mathrm{ml}$ of each dilution was plated onto nutrient agar plated as triplicate, to estimate survival fraction at each dose. All plates were incubated at $37^{\circ} \mathrm{C}$ for $24 \mathrm{hr}$. and the D 10-value was calculated for S.typhimurium.WT. strain from the dose survival curve. The samples were irradiated in $\mathrm{CO}_{60}$ facility at gamma radiation unit (4000A) at National Center for Radiation Research and Technology (NCRRT), whereas the average dose rate was $1 \mathrm{kGy} / 24 \mathrm{~min}$. at the time of the experiments. The elapsed time from irradiation exposure to plating did not exceed $15 \mathrm{~min}$., and unirradiated control was held for equivalent time periods [14] 


\section{2- Antitumor activity in vitro; cytotoxic activity} against Erihlich Ascites Carcinoma (EAC) after one hr. incubation using Trypan Blue Method:

According [15], tumor cells (EAC cells) were diluted several times with normal saline to obtain final concentration of EAC cell suspension contains $2.5 \times 10^{6}$ viable cell $/ \mathrm{ml}$. Salmonella typhimurium wild type which exposed to $\psi$-radiation at doses of $1,2,3,4,5$ and $6 \mathrm{kGy}$ were cultured in LB broth medium for $18 \mathrm{hrs} / 37^{\circ} \mathrm{C}$ to a late logarithmic phase $\left(\mathrm{OD}_{600}={ }^{0}{ }^{9}\right)$. A preliminary calibration of the cell density shows that a cell suspension with OD 600 of 1.0 is equivalent to a cell concentration of 7.5 X $10^{8} \mathrm{CFU} / \mathrm{ml}$.

Bacteria were harvested by centrifugation at 4000 rpm for $20 \mathrm{~min}$., then washed twice by BPS and diluted to a concentration of $5.0 \times 10^{6} \mathrm{CFU} / \mathrm{ml}$ in BPS [16]. The all groups were assayed in triplicates. Cells were then incubated for $1 \mathrm{hr} . / 37^{\circ} \mathrm{C}$ under a constant overlay of $5 \% \mathrm{CO} 2$. EAC viable cells were counted by trypan blue exclusion using hemocytometer. Cells were examined under microscope [17]

\section{3- Evaluation of irradiated Salmonella typhi. W.T toxicity in mice:}

The irradiated Salmonella typhimurium which show a higher anti-tumor activity in vitro were tested for their toxicity in mice; S. typhimurium $\psi$-1kGy: S.typhimurium.WT. exposed to $\psi$-radiation at dose of $1 \mathrm{kGy}$ and S.typhimurium $\psi-4 \mathrm{kGy}$ : S. typhimurium.WT. exposed to $\psi$-radiation at dose of $4 \mathrm{kGy}$. As well as, Salmonella typhi.WT. The previous mentioned bacteria were cultured in L.B. broth at $37^{\circ} \mathrm{C}$ for 18 hours to the log phase. The formula of 1 OD 600 equivalents to $7.5 \times 10^{8}$ $\mathrm{CFU} / \mathrm{ml}$ was used to estimate the bacterial concentration. Bacteria were centrifuged at 4000rpm for 15 minutes, washed twice with PBS and diluted in PBS to yield the concentration of $10^{3}, 10^{4}, 10^{5}$, $10^{6}, 10^{7}, 10^{8} \mathrm{CFU} / \mathrm{ml}$. Thirty six male mice were tested for each variant toxicity. All these dilutions of the cell suspensions were injected into the mice interaprotenial $(200 \propto 1)$, and the mice were scored for viability for a period of 3 weeks.

\section{4- Preparation of Sal. typhi. WT and its tested irradiated ones for in vivo studies:}

S. typhimurium. WT. exposed to $\psi$-radiation at dose of $1 \mathrm{kGy}$ (S. typhimurium $\psi\rangle_{-}-1 \mathrm{kGy}$ ) showed least toxicity in mice was tested in vivo for antitumor activity, as well as, S. typhimurium. WT., S. typhimurium $\psi-1 \mathrm{kGy}$. The bacterial cells were inoculated into L.B broth for 18hours (late log phase) at $37^{\circ} \mathrm{C}$, centrifuged at $4000 \mathrm{rpm}$ for $20 \mathrm{~min}$., washed twice by BPS and suspended in it (BPS). The cell suspensions were adjusted to a concentration of $2 \times 10^{4} \mathrm{CFU} / \mathrm{ml}$ for S. typhimurium. WT. and $2 \times 10^{6} \mathrm{CFU} / \mathrm{ml}$ for S. typhimurium. $\psi-1 \mathrm{kGy}$. The injection of bacterial cell suspensions were started at the first day of the experiment which last for 21 days long in all groups, except for the control and tumor groups, the injection were Intraproteinal (IP) twice and Intratumoral (IT) 3 times 4 days apart [18].

\section{5- Experimental design:}

Group 1: Animals were allowed 10 days for adaptation, then randomly equally distributed into 10 groups. Control Group 1; animals left without any treatment.

Group 2 (tumor group): Animals bearing solid Ehrlich tumor left without any treatment.

Group 3 (S. typhimurium. WT.): Animals not bearing solid Ehrlich tumor and injected with $100 \propto 1$ of S. typhimurium. WT. at dose of 1 X $10^{5} \mathrm{CFU} / \mathrm{ml}$ (IP) 4 days apart.

Group 4 (S. typhimurium. WT. + tumor); animals bearing solid Ehrlich tumor and injected with $100 \propto 1$ of S. typhimurium. WT. at dose of $2 \times 10^{5}$ $\mathrm{CFU} / \mathrm{ml}$ twice (IP) and $2001 \propto 1$ at same dose 3 times (IT) 4 days apart.

Group 5 (S. typhimurium $\psi 1 \mathrm{kGy}$ ): Animals not bearing solid Ehrlich tumor and injected with $100 \propto 1$ of S. typhimurium. $\psi-1 \mathrm{kGy}$ at dose of $2 \times 10^{6}$ $\mathrm{CFU} / \mathrm{ml}$ twice (IP) 4 days apart.

Group 6 (S. typhimurium. $\psi 1 \mathrm{kGy}+$ tumor): Animals bearing solid Ehrlich tumor and injected with $100 \propto 1$ of S. typhimurium. $\psi-1 \mathrm{kGy}$ at dose of $2 \times 10^{6} \mathrm{CFU} / \mathrm{ml}$ twice (IP) and $200 \propto 1$ at the same dose (IT) 3 times 4 days apart.

\section{6- Measurement of tumor size ( $\left.\mathrm{mm}^{3}\right)$ :}

The solid Tumor Volume (TV) $\mathrm{mm}^{3}$ was measured every four days by using Vernier Caliper according to the following equation: T.V $\left(\mathrm{mm}^{3}\right)=$ 0.52 (length $X$ width $^{2}$ ) [19], where; length, is the greatest longitudinal diameter, and width, is the greatest transvers diameter.

\section{7- Sample collection and preparation:}

At the end of the experiment (after 3 weeks) all mice were scarified and the blood samples were prepared for biochemical analysis, and tissue samples were collected and stored in $10 \%$ formalin for histopathological findings. 


\section{8- Caspase-3 activity assay:}

A549 cells were seeded in 24-well tissue culture plates and were allowed to grow until confluence and after that; the cells were infected in the conditions described on the adhesion assay. The caspase-3 activity assay followed the design described by R \& D Systems (Minneapolis, MN). After five hours of incubation, the cells were scraped and equivalent protein aliquots of each bacterial strain were determined for caspase- 3 activation. All the assays were performed in triplicate. As a negative control, non-infected A549 cells were used [20].

\section{9- Statistical analysis:}

Statistical analysis of results including the mean, Standard Error (SE), Standard Deviation (SD) and $p$ value were performed using Statistical Package for Social Science (SPSS) Version 15.0 for windows, Chicago, SPSS Inc, released 2006. All data were given as means \pm SD. Differences were considered significant at $p<0.05$.

\section{Results}

1- Sensitivity of Sal. typhi. Wild Type parant strain towards $\gamma$-radiation: The dose survival curve of Sal. typhi. WT strain was illustrated in Fig. (1). It is clear that the survival fraction of S. typhimurium. WT. was decreased by the increase of the exposure dose to $\gamma$ radiation.

A significant reduction $(p \leq 0.001)$ of S. typhimurium. WT. count was recorded compared to non-irradiated control, and the wild type strain exhibited an exponential rate of death. The $\mathrm{D}_{10-}$ value was 0.7 for the S. typhimurium. WT. parent strain.

2- Cytotoxic effect of Sal. typhi. WT that exposed to $\gamma$-irradiation against EAC cells after $1 \mathrm{hr}$. incubation using trypan blue method: The cytotoxicity data of S. typhimurium. WT. which exposed to different doses of $\gamma$-radiation against EAC cells after one hr. incubation was illustrated in Fig. (2). S. typhimurium. WT. exposed to $1 \mathrm{kGy}$ recorded the highest mortality percent $(66 \%)$ followed by that was exposed to $4 \mathrm{kGy}$ which recorded a mortality percentage of 56. On the other hand, S. typhimurium. WT. and those which exposed to $0.5 \mathrm{kGy}$ recorded the least mortality percentage of 21 and 32, respectively.

3- Toxicity and lethality of S. typhimurium. WT. ATCC (14028) exposed to 1 and $4 k G y \quad \gamma$-radiation in mice: After 21 days of injection, the mortality incidence percentage in all groups was recoded and illustrated in Fig. (3). Results showed that no mortality occurred in all mice after the injection by concentrations $10^{2}, 10^{3}$ and $10^{4} \mathrm{CFU} / \mathrm{ml}$ of $\mathrm{S}$. typhimurium. WT., S. typhimurium. $\gamma-1 \mathrm{kGy}$ and S. typhimurium. $\gamma 4 \mathrm{kGy}$. The data indicated that S. typhimurium. WT. was more virulent to mice than those which subjected to 1 and $4 \mathrm{kGy}$. This result was obtained since the wild type strain had recorded $100 \%$ mortality in mice when injected by a concentration of $10^{7}, 10^{8} \mathrm{CFU} / \mathrm{ml}$, meanwhile, the wild type one which exposed to $1 \mathrm{kGy}$ was less virulent to mice than the wild type and that which exposed to $4 \mathrm{kGy}$.

4- Tumor volume: After the tumor volume reached, approximately $1 \mathrm{~cm}^{3}$, the measurements were obtained for consecutive treatments of the animals with S. typhimurium.WT and S. typhimurium. $\gamma-1 \mathrm{kGy}$ for 21 days and the results were illustrated in Fig. (4). A marked suppression in tumor growth was noticed on days of 10, 14, 17 and 21 due to the bacterial treatments.

Measurement of tumor volume at day 21 in mice bearing tumor that treated with S. typhimurium. WT. and S. typhimurium. $\gamma-1 \mathrm{kGy}$ revealed a significant $(p \leq 0.001)$ regression in the growth comparing with tumor control group $(1672 \pm 123$ vs $3726 \pm 102 \mathrm{~mm}^{3}$ and $1482 \pm 98$ vs $3726 \pm 102 \mathrm{~mm}^{3}$, respectively).

5- Serum Caspase-3 activity in different mice groups (unit $/ \mathrm{ml}$ ): The results in (Table 1) revealed that the treatment of mice bearing tumor with $\mathrm{S}$. typhimurium. $\gamma-1 \mathrm{kGy}$ showed highly significant increase $(p \leq 0.001)$ in caspase- 3 activity levels compared to its level in mice bearing tumor group treated with S. typhimurium. WT.

\section{6- Histopathological findings:}

A- Group of mice kept as control: There was no histopathological alteration and the normal histological structures of the bundles were recorded in Photo (1).

B- Group of mice bearing solid tumor: Most of the Ehrlich tumor cells in the thigh muscles were histological intact Photos (2-4). Inflammatory cells infiltration was observed in between the muscle bundles Photo (5).

$C$ - Group of mice bearing solid tumor treated with S. typhimurium. WT.: The result of histological analysis illustrated that the Hyalinization was noticed in the muscle bundles associated with inflammatory cells infiltration as well as between the tumor cells Photo (6). Nuclear pyknosis was detected in some of the Ehrlich tumor cells Photos $(7,8)$. There were inflammatory cells infiltrations, 
as well as, focal hemorrhages between the muscle bundles Photo (9).

D- Group of mice bearing solid tumor treated with S.typhimurium. $\gamma-1 k G y$ : Defined demarcation line of inflammatory cells and collagen fibers was noticed and separating the multiple fragmented and nuclear pyknotic nuclei of the Ehrlich tumor cells from the musculature Photos (10-12). There was inflammatory cells infiltration in between the muscle bundles.

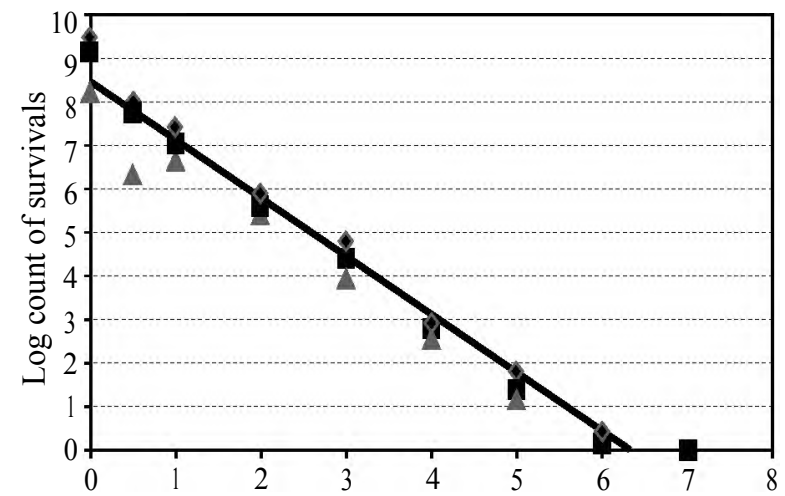

Fig. (1): Dose response curve of Salmonella typhimurium WT towards Gamma irradiation.

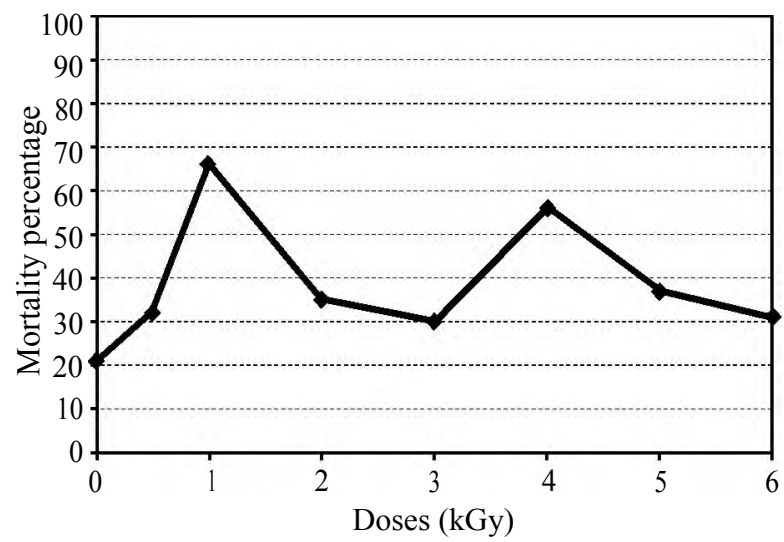

Fig. (2): Cytotoxicity of Salmonella typhimurium.WT. strain exposed to different doses of Gamma-irradiation against EAC cells after $1 \mathrm{hr}$. incubation period.

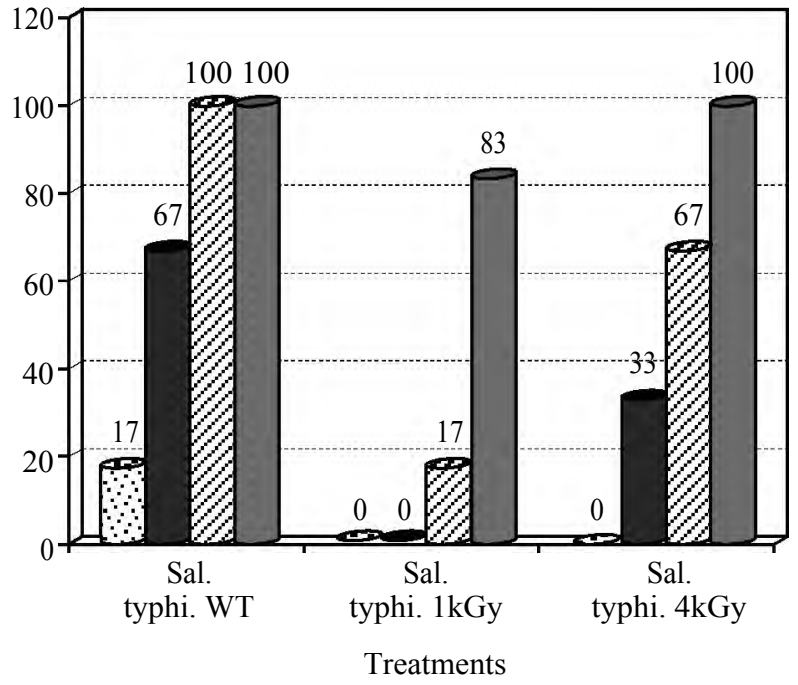

Fig. (3): Percentage of mortality of Salmonella typhimurium. WT. strain and its variants in mice.
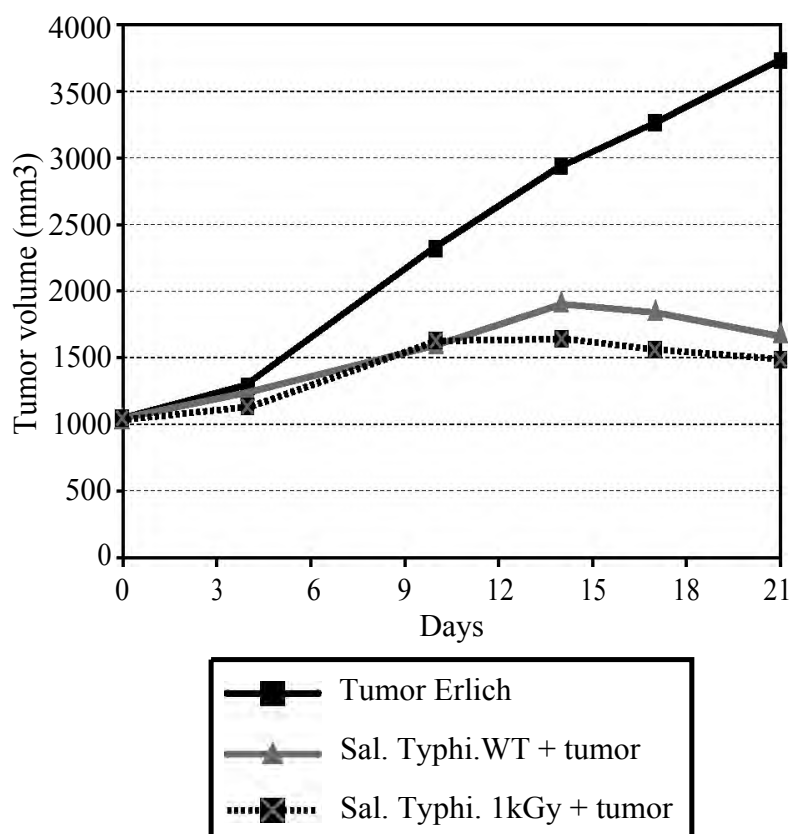

Fig. (4): Values of tumor volumes $\left(\mathrm{mm}^{3}\right)$ im mice bearing tumor groups.

Table (1): Caspase-3 activity in the different mice groups treated (unit $/ \mathrm{ml}$ ).

\begin{tabular}{|c|c|c|c|c|c|c|c|c|}
\hline \multirow{2}{*}{ Group } & \multirow{2}{*}{ Mean \pm SD } & \multicolumn{6}{|c|}{ Probability value ( $p$-value) } & \multirow{2}{*}{$\frac{\% \text { change }}{\text { from control }}$} \\
\hline & & $p$ vs 1 & $p$ vs 2 & $p$ vs 3 & $p$ vs 4 & $p$ vs 5 & $p$ vs 6 & \\
\hline 1. - ve control & $1.1 \pm 0.04$ & & & & & & & \\
\hline 2. Tumor & $3.7 \pm 0.23$ & 0.001 & & & & & & +260 \\
\hline 3. S. typhimurium. WT. & $1.3 \pm 0.12$ & N.S & 0.001 & & & & & +18 \\
\hline 4. S. typhimurium. WT. + Tumor & $4.3 \pm 0.29$ & 0.001 & 0.001 & 0.001 & & & & +290 \\
\hline 5. S. typhimurium. $\gamma-1 \mathrm{kGy}$ & $1.45 \pm 0.1$ & 0.001 & N. S & 0.001 & 0.001 & & & +32 \\
\hline 6. S. typhimurium $\gamma-1 \mathrm{kGy}+$ Tumor & $5.3 \pm 0.3$ & 0.001 & 0.001 & 0.001 & 0.018 & 0.002 & & +382 \\
\hline
\end{tabular}




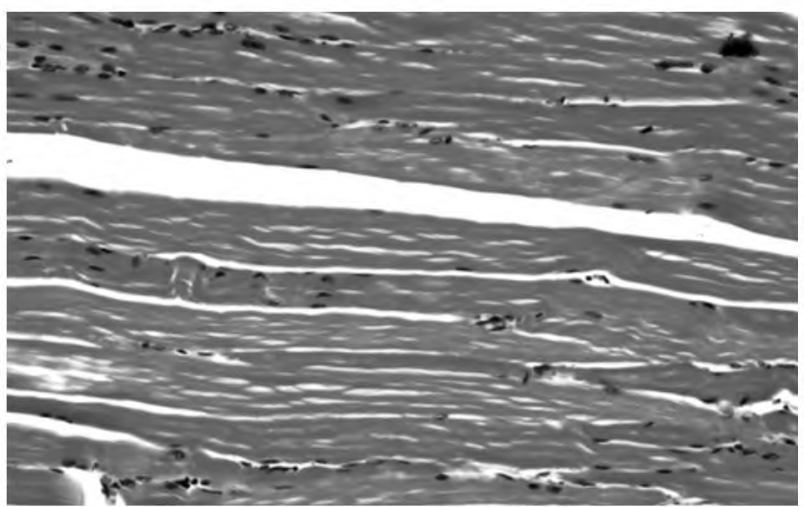

Photo (1): The muscle of mice in group showing normal histopathological structure of the muscle bundles.

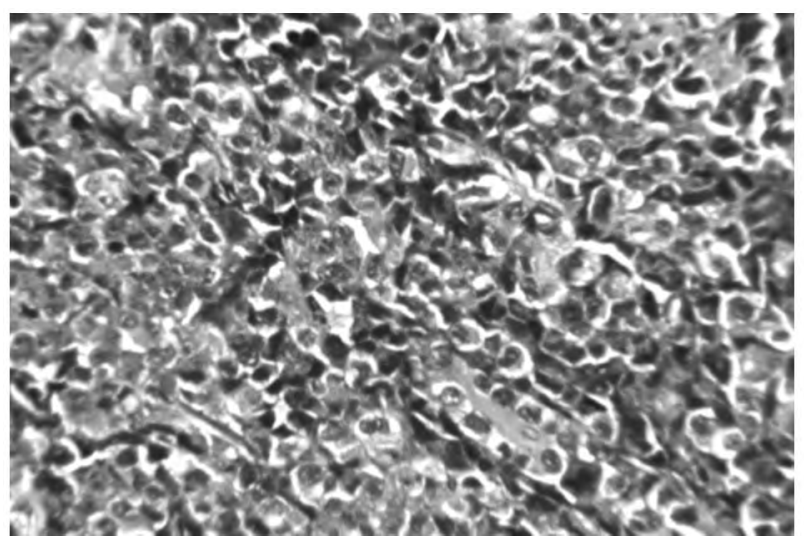

Photo (3): Ehrlich tumor cells in thigh muscle of mice group (2) showing the magnificent of Photo (2) to identify the histological structure (cc).

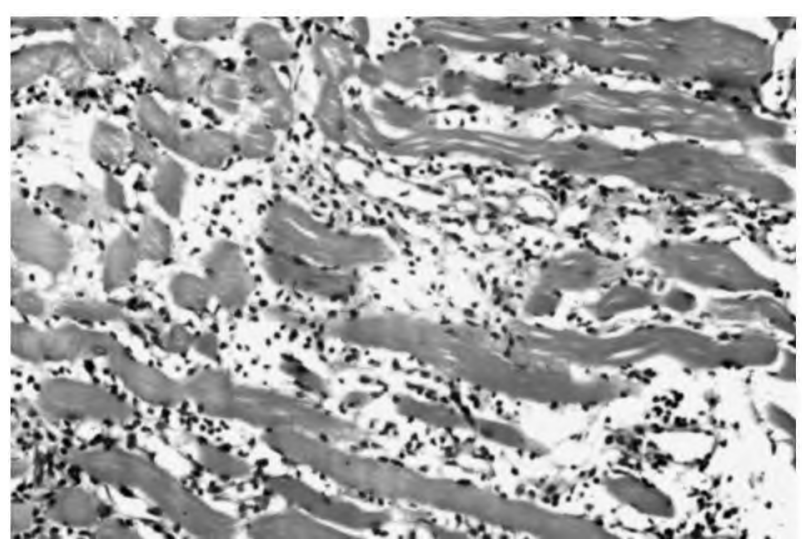

Photo (5): Thigh muscle of mice group (2) showing inflammatory cells infiltration $(\mathrm{m})$ in between the bundles $(\mathrm{ml})$.

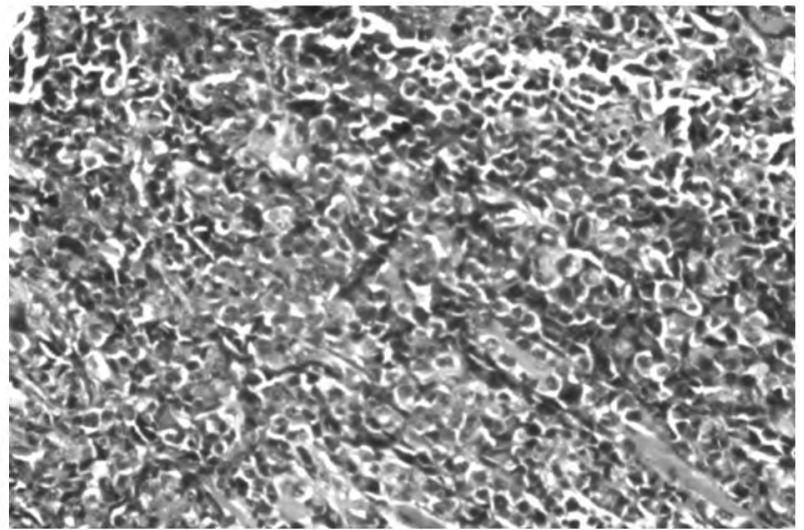

Photo (2): Ehrlich tumor cells thigh muscle of mice groups showing interact histopathological structure of most of the tumor cells (ec).

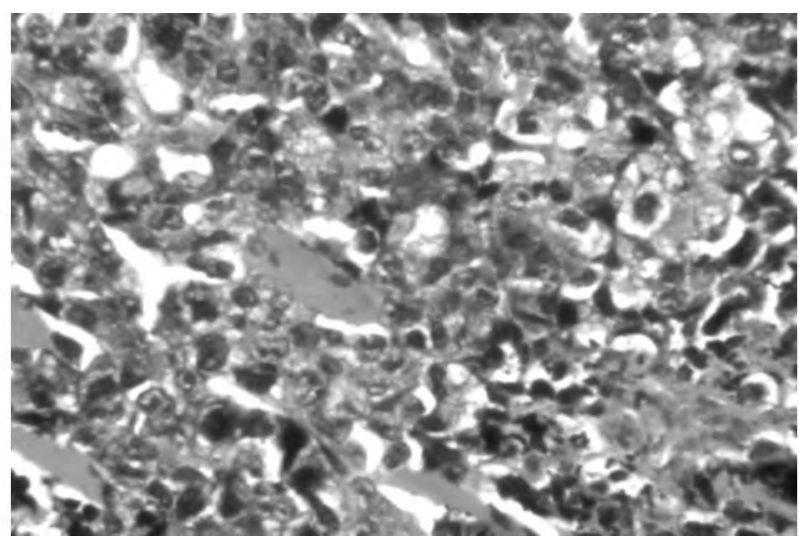

Photo (4): Ehrlich tumor cells in thigh muscle of mice groups (2) showing the magnificent of Photo (3).

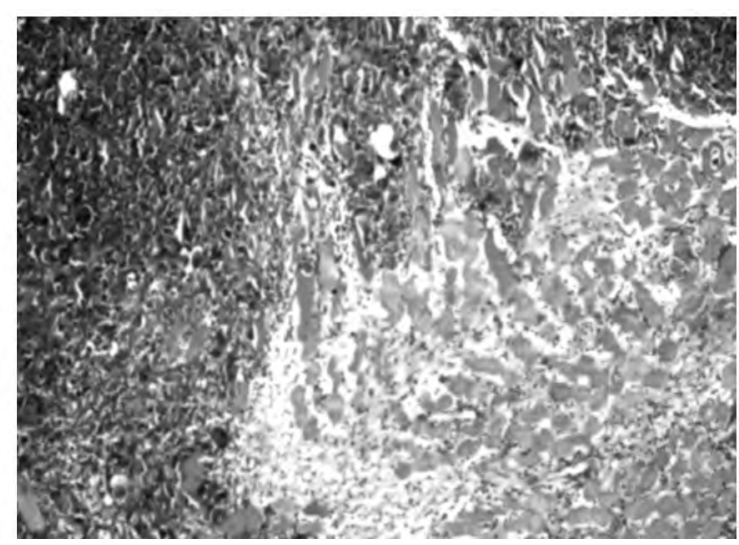

Photo (6): Ehrlich tumor cells $m$ thigh muscle of mice group (4) showing hyalinization in skeletal muscle bundle $(\mathrm{ml})$ with inflammatory cells infiltration $(\mathrm{m})$ in between the tumor cells and muscle bundles. 


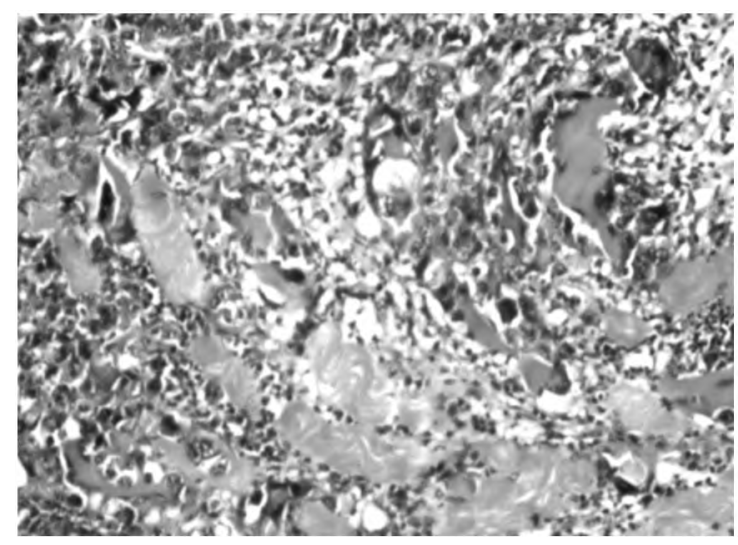

Photo (7): Ehrlich tumor cells in thigh muscle of mice group (4) showing pyknosis in the muscle of some tumor cells (cc).

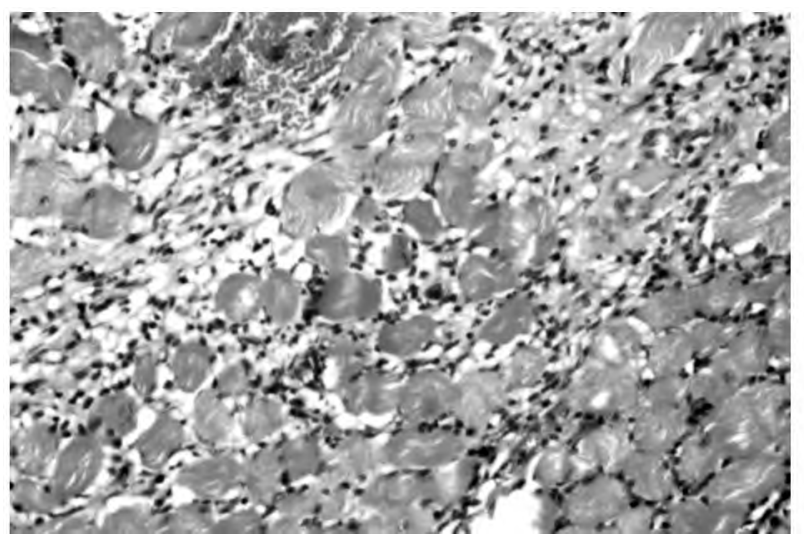

Photo (9): Skeletal muscle in mice group (4) showing inflammatory cells infiltration $(\mathrm{m})$ and focal hemorrhage (b) in between the hyaline zed muscle bundles.

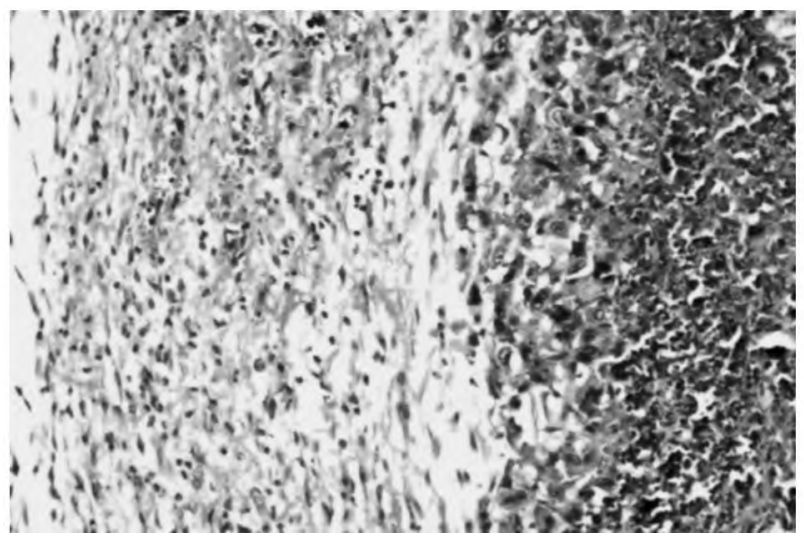

Photo (11): Ehrlich tumor cells in thigh muscle of mice group (6), showing the magnification of Photo (10) to identify the inflammatory reaction of collagen (m) with the necrosis in tumor cells (NCC).

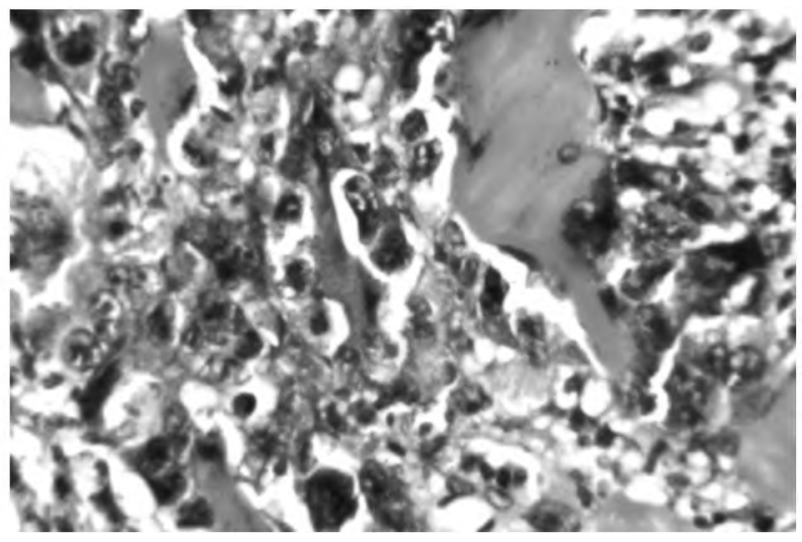

Photo (8): Ehrlich tumor cells in thigh muscle of mice groups1 showing the magnification of Photo (7) to identify the pyknosis in nuclei of tumor cells (cc).

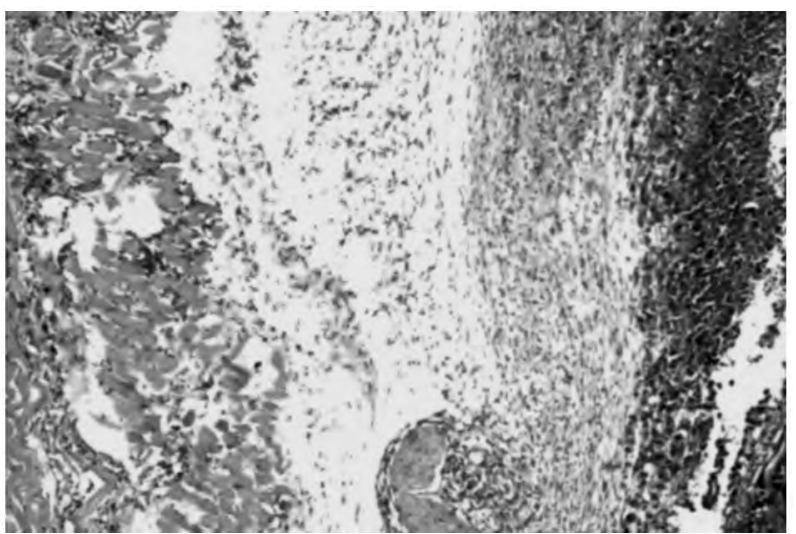

Photo (10): Ehrlich tumor cells in thigh muscle of mice group (6) showing inflammatory cells infiltration (m) with collagenous proliferation defined the skeletal muscle $(\mathrm{m})$ of the necrosis in the tumor cells (NCC).

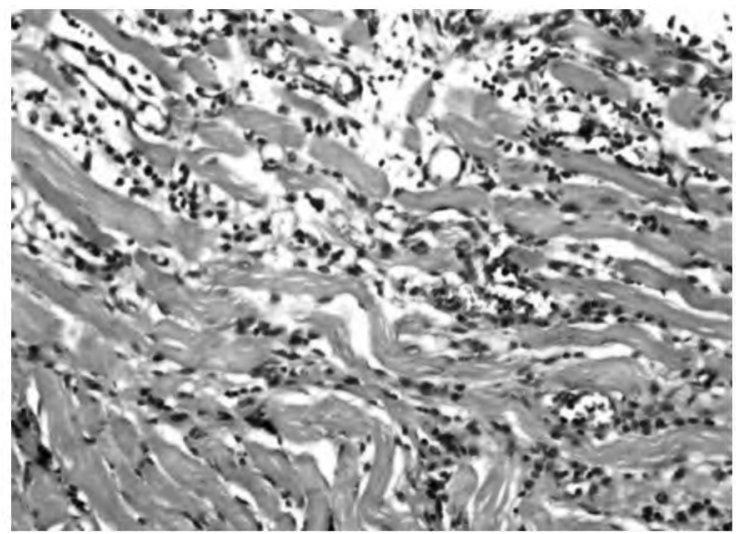

Photo (12): Thigh muscle of mice m group (6) showing inflammatory cells infiltration $(\mathrm{m})$ in between the bundles. 


\section{Discussion}

The present investigation was aimed to study the potential of enhancing the S. typhimurium . WT. by radiation on preventing solid tumor incidence.

It was found that S. typhimurium. Exerted a direct intrinsic toxic effect on EAC cells by different level according to its ability to invade and affect the EAC cell line but the maximum inhibition was for S. typhimurium. $\psi-1 \mathrm{kGy}$ this results supported by [5].

Once Salmonella has infected the eukaryotic cell line, bacterial proliferation and expression of certain bacterial proteins during the first hours of infection induce cells death [21]. This prove and support the results obtained in the present study.

The present experimental data indicated that the exposure of S. typhimurium. WT. strain ATCC 14028 to $1 \mathrm{KGy}$ Gamma radiation dose become partially inactivated which leads to decrease its virulence in mice, which was in agreement with [22] who explained this results as follow; the S. typhimurium. WT. attenuation was due to cells surface damage as result of interaction of extra cellular hydroxyl radicals and oxygen, and intra cellular DNA damage.

Since $50 \%$ to $70 \%$ of bacterial cell mass is water, it absorbs much of the radiation. As a result hydroxyl radiates and hydrated electrons, which are important in irradiation-included cell inactivation, are produced [23].

[24] proved that ionizing irradiation can produce a variety of damaging effect in base and sugar moieties of the plasmid in DNA which lead to mutation and inactivation.

Irradiation damage of DNA is considerable a major cause of cell inactivation, which those of protein, lipid land RNA contribute less, since reaction of DNA with hydroxyl radicals may result in single-and/or double strand breaks, proteinDNA cross-linkage, and base alternation leading to cellular inactivation [25].

This investigation cleared that visual inspection of the treated tumor bearing mice, as well as, analysis of histopathologic section of tumor showed a control necrosis with growth of S. typhimurium. $\psi-1 \mathrm{kGy}$ variant within the tumor, as well as significant reduction $(p<0.001)$ of tumor growth was seen in mice receiving S. typhimurium. WT. and S. typhimurium $\psi-1 \mathrm{kGy}$ compared with tumor control. These was in agreement with [26-28] who reported that possible mechanism to explain the slowing of tumor growth by Salmonella include the consumption of nutrients by bacteria needed of tumor growth, the production of enzymes by bacteria such as asparaginase that can deplete essential amino acids needed by the tumor, the secretion of local toxins into the extra cellular environment, or the stimulation of tumor necrosis factor-alpha a production, which can import tumor vasculature. The non-specific inflammatory Reponses seen at the site of bacterial growth could also potentially activate antitumor T-cells.

[29] reported that the activation of the caspase3 is enough to come to the conclusion that Salmonella typhimurium is inducing apoptosis on the adenocarcinomic cell. Furthermore, it causes programmed cellular death on the tumor makes this bacteria an important and promising candidate for the development of a new therapy based on living organisms.

The treatment with S. typhimurium.WT. exposed to $1 \mathrm{kGy}$ improved the outcome in solid tumor regression, and induces apoptotic process through caspase- 3 activation [30].

This is consistent with our previous results which reveals that $S$. typhimurium may activate specific apoptotic enzymes including caspase-3 through S. typhimurium effector SipA. The activation of caspase- 3 in turn increases the infectivity of this pathogen by enhancing the secretion of effectors Furthermore, the activation of cleaved caspase-3 is linked to tumor cell apoptosis [5]

In the present work, the results showed a significant increase in caspase-3 activity, in mice that treated with $\mathrm{S}$. typhimurium $\psi-1 \mathrm{kGy}$ more than those that treated with S. typhimurium.WT. These findings was in agreement with [31] and [11] who reported that $\mathrm{S}$. typhimurium is being used to target and destroy tumors through sensitizing the immune system to the presence of tumors, and also directly activate caspase-3, a key enzyme of the apoptotic pathway.

The Hematoxylin and Eosin (H \& E) staining of tumor tissues showed that the Salmonella typhimurium colonization in mice solid tumor resulted in a sharper increase in the number of necrotic solid tumor cells [30,32].

In this study, histopathological finding revealed that treatment of mice bearing tumor groups with S. typhimurium that exposed to $\psi$ radiation showed, a histopathological improvement compared to tumor group. 
In the present study histopathological finding of muscular thigh tissue of the mice bearing tumor treated with S. typhimurium 1-kGy showed approximately normal Histological structure compared to the control healthy group which agreement with muscular and biochemical parameters.

\section{Conclusion:}

It was concluded that the exposure of Salmonella typhimurium wild type to gamma irradiation produced an attenuated Salmonella typhimurium capable of tumor targeting, colonizing and eliciting growth suppression of solid tumor in mice.

\section{References}

1- ZHANG Y., MIWA S., ZHANG N., HOFFMAN R.M. and ZHAO M.: Tumor-targeting Salmonella typhimurium A1-R arrests growth of breast-cancer brain metastasis. Oncotarget., 6: 2615-22, 2015.

2- LOEFFLER M., Le'NEGRATE G., KRAJEWSKA M. and REED J.C.: IL-18-producing Salmonella inhibit tumor growth. Cancer Gene. Ther., 15: 787-94, 2008.

3- HOFFMAN R.M.: Future of Bacterial Therapy of Cancer Methods in Molecular Biology. Series Methods in Molecular Biology, 1409: 177-84, 2016.

4- PHAN T.S., HONG N., MAI T.D., YEONGJIN H., HYON E. and JUNG-JOON M.: Activation of inflammasome by attenuated Salmonella typhimurium in bacteria-mediated cancer therapy. Microbiol. Immunol., 59: 664-75, 2015.

5- LI C.X., BIN Y., LEI S., WEI G., QIU-BIN L., CHANGCHUN L., MEI Y., KEVIN T.P.N., JIAN-DONG H. and KWAN M.: Obligate' anaerobic Salmonella strain YB 1 suppresses liver tumor growth and metastasis in nude mice. Oncol. Lett.; 13 (1): 177-83, 2017.

6- PAWELEK J.M., LOW K.B. and BERMUDES D.: Tumortargeted Salmonella as a novel anticancer vector. Cancer Res., 57: 4537-44, 1997.

7- HAHN H.P. and VON SPECHT B.U.: Secretory delivery of recombinant proteins in attenuated Salmonella strains: Potential and limitations of Type I protein transporters. F.E.M.S. Immunol. Med. Microbiol., 37: 87-98, 2003.

8- ZHAO L., ZHANG L., GAO L., GUO B., JI K. and TIAN Y.: Intratumoral delivery and suppression of prostate tumor growth by attenuated Salmonella enterica serovar typhimurium carrying plasmid-based small interfering RNAs. Cancer Res., 67: 5859-64, 2007.

9- MENGESHA A., DUBOIS L., LAMBIN P., LANDUYT W. and CHIC R.K.: Development of a flexible and potent hypoxia-inducible promoter for tumor-targeted gene expression in attenuated Salmonella. Cancer Biol. Ther., 5: 1120-8, 2006.

10- SEONG S.: Application of radiation technology in vaccines development. Clin. Exp. Vaccine Res.; 4: 145-58, 2015.

11- WALL D.M., SRIKANTH C.V. and BETH A.: Targeting Tumors with Salmonella typhimurium. Oncotarget, 1 (8): 721-72, 2010.

12- GUPTA M., MAZUMDER U.K., KUMAR R.S. and KUMAR T.S.: Antitumor activity and antioxidant role of
Bauhinia racemosa against Ehrlich ascites carcinoma in Swiss albino mice. Acta. Pharmacol., Sin., 25 (8): 10706, 2004.

13- HARRIS D.R., POLLOCK S.V., WOOD E.A., GOIFFON R.J., KLINGELE A.J., et al.: Directed ecaluation on ionizing radiation resistance in Escherichia coli. Journal of Bacteriology. Aug., 5240-52, 2009.

14- RUSSELL A.D.: Effects of ionizing radiation on bacterial spore. In "Destruction Bacterial spore": Acad. Pres., Inc., London. Ltd., pp. 31-109, 1982.

15- MARASHI S.A., TAVIRANI M.R. HAKLMEH, ZALI H. and SHOKRGOZAR M.A.: Mitochondria DNA might be influenced in calprotection-induced cell death. EXCLI J., 7: 163-8, 2008.

16- KARABAY A.Z., KOC A., OZKAN T., HEKMATSHOAR Y., SUNGUROGLU A., AKTAN F. and BUYUKBINGOL A.: Methyl sulfonyl methane induces P53 Independent Apoptosis in HCT-116 colon cancer cells. Int. J. Mol. Sci., July 15; 17 (7): 1123-42, 2016.

17- RIBEIRO D.A., MARQUES M.E. and SALVADORI D.M.: In vitro cytotoxic and non-genotoxic effects of Gutta-Percha solvents on mouse lymphoma cells by single cell gel (comet) assay. Braza. Dent. J., 17 (3): 228-32, 2006.

18- ARRACH N., CHENG P., ZHAO M., SANTIVIAGO C.A. and HOFFMAN R.M. and McCLELLAND M.: High-throughput screening for salmonella a virulent mutants that retain targeting of solid tumors. Cancer Res., 70 (6): 2165-70, 2010.

19- JENSEN M.M., JORGENSEN J.T., BIODERUP T. and KJAER A.: Tumor volume in subcutaneous mouse xenografts measured by micro CT is more accurate and reproducible than determined by $18 \mathrm{~F}-\mathrm{FDG}$-micro PET or external cliper. Bio. Med. Central Med. Imaging, 8: 16, 2008.

20- CHATTERIJEE P., KRISHNA G., NITIN Y. and SANTOSK R.K.: A Noval-L-Fucose-Binding Lectin from Fenneropenaeus indicucs induced cyto toxicity in Breast Cancer Cells. J. Biochem., 13. 161: (1): 87, 2016.

21- PEREIRA B.S., CARLOS M., EVA M.C. and AMANDOM F.: Improved cytotoxic effects of Salmonellaproducing cytosine deaminase in tumor cells. Microb. Biotechnol. Jan., 8 (1): 169-76, 2015.

22- KIM A.Y. and THAYER D.W.: Mechanism by which gamma irradiation increases the sensitivity of Salmonella typhymurium ATTC 14028 to heat. Appl. Environ. Microbiol., May: 1759-63, 1996.

23- VON SONNTAG C.: The chemical bases of radiation biology. Taylor and Francis, London, 1987.

24- KIM A.Y. and THAYER D.W.: Radiation induced all lethality of Salmonella ATTC 14028: Cooperative effect of hydroxyl radical and oxygen. Radiat. Res., 126: 257366, 1994

25- WATERS L.C., SKIPI M.O., PRESTON J., MITRA S. and JABERABOAN A.: Mutation induced by ionizing radiation in a plasmid replicated in human cell. Rad. Res., 127: 191-210, 1991.

26- ROSENBERG S.A., SPIESS P.J. and KLEINER D.E.: Antitumor effects in mice of theintravenous injection of 
attenuated Salmonella typhymurium. J. Immonutherapy, 25 (3): 218-25, 2002.

27- MOMIYAMA M., ZHAO M., KIMURA H., TRAN B., CHISHIMA T. and BOUVET M.: Inhibition and eradication of human glioma with tumor-targeting Salmonella typhimurium in an orthotopic nude-mouse model. Cell Cycle, 11: 628-32, 2012.

28- KUZMIERCZAK R.A., GENTRY B., MUMM T., SCHATTEN H. and EISENSTARK A.: Salmonella Bacterial Monotherapy Reduces Autochthonous Prostate Tumor Burden in the TRAMP Mouse Model. PLoS ONE, 11 (8): 1-16, 2016.

29- IZIDORO M.S., Jr. VARELA J.N., ALVES D.A., PEREIRA R.F.C. and BROCCHI M.: Effects of Salmonella enteritidis serovar typhimurium Infection in Adenocarcinomic Human Alveolar Basal Epithelial Cells A549 In vitro: Bacteria Induce Apoptosis in Adenocarcinomic Cell. J. Bacteriol. Parasitol., 3: 158-63, 2012.

30- SHI L., BIN Y., CHUN-HUI C. and JIAN-DONG H.: Angiogenic inhibitors delivered by the type III secretion system of tumor-targeting Salmonella typhimurium safely shrink tumors in mice, A.M.B. Expr., (6): 56-66, 2016.

31- SRIKANTH C.V., WALL D.M., MALDONADOCONTRERAS A., SHI H.N., ZHOU D., DEMMA Z., MUMY K.L. and McCORMICK B.A.: Salmonella pathogenesis and processing of secreted effectors by caspase3. Science, 10: 330-90, 2010.

32- CHANG J.J., YITING Q.Y., TANG T., GUO C., XIUFENG L., BINGYA Y., JING W., XIANGYU Z., XIAWEI C., PAN D., WENHUI J., QINGANG H. and ZI-CHUN H.: Modulation of Salmonella Tumor-Colonization and Intratumoral Anti-angiogenesis by Triptolide and Its Mechanism., Theranostics, 7 (8): 2250-60, 2017.

\section{السالمونيلا تايفيميوريه المعالجة بالإشعاع الجامى

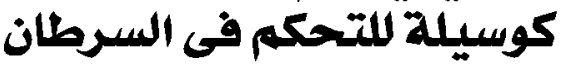

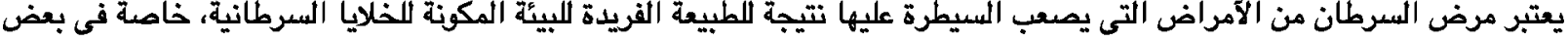
حالات الأهدام الصلبة. ويعزى هذا للنقص الشديد في الآ كسجين بها فضلا عن علم وجود آوعية دموية مما يصعب الوصول إليها وعلاجها.

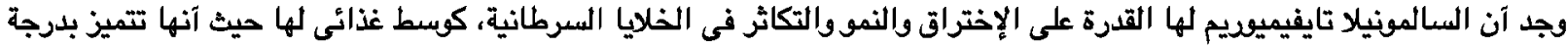
عالية من التخصص فى الإنتشار والتكاثر فى النسيج الودمى، وتهدف هذه الدراسة إلى بحث إمكانية إستخدام الآثعة المؤينة (آثعة جاما) لآضعاف السالمونيلا تايفيميويم الآصلية تكفن لها القدرة على إستهداف وتقليص حجم الوندم، ولتحقيق هذه الهدف ولمعرفة مدى إمكانية

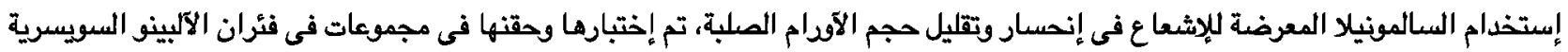

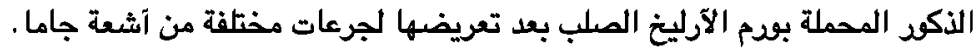

قد آوضصت النتائج آن تعرض العالمونيلا تايفيميويم للإشعاع قد آدى إلى إضعافها، وبالتالى آصبح تآثيرها آقل سمية لفئران التجارب.

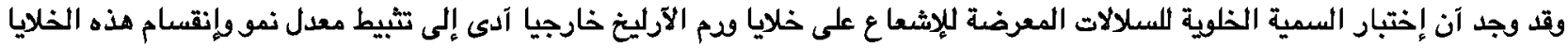

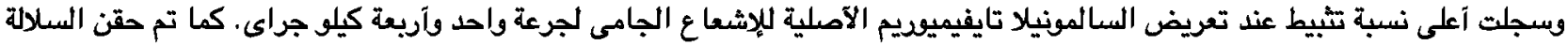

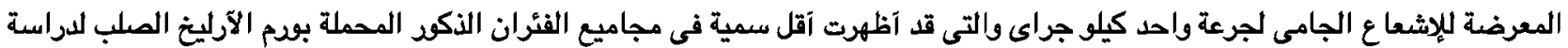
مدى تآثيرها على حجم الودم كذلك تم تقدير مستوى نثاط كاس باس بأ فى نسيج الودم بالإضافة إلى دراسة قطاعات الآنسجة العضلية المحملة

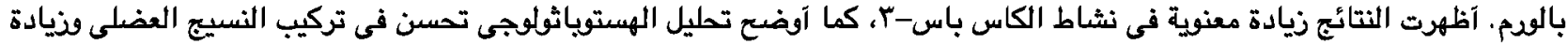

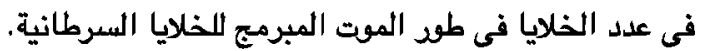

